\title{
Meningkatkan Profitabilitas Dengan Menerapkan Islamic Corporate Identity (Studi Pada Bank Umum Syariah di Indonesia Tahun 2014-2017)
}

\author{
Purwanto \\ Sekolah Tinggi Agama Islam Al Husain, Magelang \\ Email: poerwanto073@gmail.com
}

\begin{abstract}
Abstrak:
It is important for Islamic banking to provide information to the public that Islamic banking has an identity that is different from conventional banking. An important Islamic Corporate Identity for sharia banking is because it is one of the information for customers to use Islamic bank products, so the better the implementation of Islamic Corporate Identity, the more opportunities for Islamic banking to get investors and ultimately to increase profits. The purpose of this study is to find out how Islamic Corporate Identity influences profitability. This research was conducted on 12 Islamic public banks for the period 2014-2017. The data analysis technique used is panel data regression. From the results of panel data regression analysis, the results show that the Islamic Corporate Indentity variable in Islamic Commercial Banks in Indonesia in 2014-2017 has a positive significant effect on Profitability, this can be seen from the Prob value of $0.0045>0.05$. Thus the better the Islamic Corporate Indentity in Islamic Commercial Banks is the profitability of the bank.

[Penting bagi perbankan syariah untuk memberikan informasi pada masyarakat bahwa perbankan syariah memiliki identitas yang berbeda dengan perbankan konvensional. Islamic Corporate Identity penting bagi perbankan syariah karena menjadi salah satu informasi untuk nasabah untuk menggunakan produk bank syariah, sehingga semakin baik penerapan Islamic Corporate Identity maka semakin banyak kesempatan bagi perbankan syariah untuk mendapatkan investor dan pada akhirnya dapat meningkatkan keuntungannya. Tujuan dari penelitian ini adalah untuk mengetahui bagaimana pengaruh Islamic Corporate Identity terhadap profitabilitas. Penelitian ini dilakukan terhadap 12 bank umum syariah periode 2014-2017. Teknik analisis data yang digunakan adalah regresi data panel. Dari hasil analisis regresi data panel diperoleh hasil bahwa variabel Islamic Corporate Indentity pada Bank Umum Syariah di Indonesia tahun 2014-2017 berpengaruh signifikan positif terhadap Profitabilitas (ROA) hal ini dapat dilihat dari nilai Prob 0,0045 > 0,05. Dengan demikian semakin baik Islamic Corporate Indentity pada Bank Umum Syariah maka profitabilitas bank.]
\end{abstract}

Kata Kunci: Bank Syariah; Islamic Corporate Identity; Profitabilitas. 


\section{PENDAHULUAN}

Disahkannya Undang-Undang No. 21 Tahun 2008 tentang Perbankan Syariah pada tanggal 16 Juli 2008 industri perbankan syariah di Indonesia mengalami perkembangan yang pesat. Selain adanya kepastian hukum mengenai keberadaan institusi perbankan syariah, perkembangan perbankan syariah juga didukung oleh banyaknya penduduk di Indonesia yang beragama Islam. Ajaran agama khusunya Islam yang melarang praktik riba ${ }^{1}$ dalam aktivitas bisnis, maka kehadiran perbankan syariah dinilai oleh masyarakat dapat menjadi alternatif untuk menyimpan dan menggunakan produk bank syariah. Faktor inilah yang menyebabkan bank syariah berkembang pesat di Indonesia. Perkembangan tersebut dapat dilihat dari Statistik Perbankan Syariah pada tabel 1. berikut:

Tabel 1

Perkembangan Total Aset Perbankan Syariah (dalam Milliar)

\begin{tabular}{llll}
\hline Tahun & $\begin{array}{l}\text { Bank Umum } \\
\text { Syariah* }\end{array}$ & Unit Usaha Syariah* & $\begin{array}{l}\text { Bank Pembiayaan } \\
\text { Rakyat Syariah** }\end{array}$ \\
\hline 2014 & 204.961 & 67.383 & 6.573 \\
\hline 2015 & 213.423 & 82.839 & 7.739 \\
\hline 2016 & 254.184 & 102.320 & 9.157 \\
\hline 2017 & 288.027 & 136.154 & 10.840 \\
\hline $2018^{*}$ & 304.292 & 149.957 & 11.929 \\
\hline
\end{tabular}

Sumber: Statistik Perbankan Syariah 2018

* Data s/d Oktober 2018

Tabel di atas memberikan informasi bahwa dari segi aset perbankan syariah mengalami perkembangan yang positif dalam kurun waktu lima tahun. Perkembangan perbankan syariah di Indonesia tidak hanya pada jumlah aset saja, namun dari sisi jumlah bank dan jumlah kantor juga mengalami peningkatan. Hal ini membuktikan bahwa perbankan syariah semakin mampu menunjukkan eksistensinya dalam memberikan pelayanan pada industri keuangan syariah.

Eksistensi perbankan syariah di Indonesia harus dipertahankan, sehingga mampu bersaing dengan perbankan non syariah. Guna menjaga eksistensi tersebut maka menurut Sukardi penting bagi perbankan syariah untuk membangun citra kepada masyarakat bahwa dalam memberikan pelayanan kepada masyarakat memegang prinsip-prinsip syariah. Citra positif ini dapat ditunjukkan melalui aktivitas bisnis dimana perbankan hanya menawarkan produk dan layanan jasa keuangan yang sesuai dengan prinsip-prinsip syariah. ${ }^{2}$ Perbankan syariah juga harus memberikan citra positif dengan menonjolkan aspek keadilan dalam bertransaksi, investasi yang beretika, mengedepankan nilai-nilai kebersamaan dan persaudaraan, serta menghindari kegiatan spekulatif dalam bertransaksi. ${ }^{3}$ Citra positif ini harus ditonjolkan karena merupakan identitas dari perusahaan yang berbasis syariah.

Penting bagi perbankan syariah untuk memberikan informasi pada masyarakat bahwa perbankan syariah memiliki identitas yang berbeda dengan perbankan konvensional. Identitas perusahaan merupakan salah satu elemen penting dalam strategi komunikasi

\footnotetext{
1 Taufik Ariyanto, "Analisis Pengaruh Pengungkapan Identitas Etis Islam Terhadap Kinerja Keuangan Bank Syariah Di Asia," Jurnal Akuntasi Dan Keuangan 1, no. 1 (2014): 98-110.

2 Budi Sukardi and Taufiq Wijaya, "Corporate Ethical Identity Perbankan Syariah Di Indonesia," Jurnal Tsaqafah 9, no. 2 (2013): 337-356.

${ }^{3}$ Ratih Paramitasari, "Islamic Corporate Identity in the Practice of Annual Report Disclosure Islamic Bank," ASSETS: Jurnal Akuntansi Dan Pendidikan 1, no. 1 (2012): 34-44.
} 
perusahaan, dimana hal tersebut mencerminkan rencana perusahaan yang matang. Identitas perusahaan yang baik sejalan dengan strategi dan rencana perusahaan, sehingga berimplikasi pada terciptanya reputasi perbankan syariah, yaitu persepsi masyarakat terhadap produkproduk perbankan syariah. ${ }^{4}$ Identitas perusahaan diyakini dapat memberikan dampak positif terhadap reputasi perusahaan, sehingga mendapat respon positif dari praktisi dan akademisi. ${ }^{5}$ Penting bagi perusahaan untuk mempertahankan reputasinya karena dapat memberikan jaminan bahwa perusahaan memiliki kemampuan untuk mendapatkan keuntungan dari waktu ke waktu. Keuntungan yang stabil pada akhirnya dapat mengingkatkan kinerjanya. ${ }^{6}$

Identitas perbankan syariah sebagai perusahaan yang memegang prinsip-prinsip syariah dapat dilihat dari unsur-unsur Islamic Corporate Identity. Menurut Haniffa dan Hudaib ada delapan dimensi yang menunjukkan Islamic Corporate Identity diantaranya adalah 1) Pernyataan mengenai visi dan misi; 2) Dewan komisaris dan manajemen puncak, 3) Produk dan layanan, 4) Zakat, infak, dan shodaqoh, serta dana kebajikan, 5) Komitmen terhadap karyawan. 6) Komitmen terhadap debitur. 7) Komitmen terhadap lingkungan masyarakat dan 8) Dewan Pengawas Syariah. ${ }^{7}$

Islamic Corporate Identity dapat dilihat dalam laporan tahunan setiap perbankan syariah, sehingga dapat dibaca oleh semua pihak yang berkepentingan. Dengan demikian laporan tahunan dapat menjadi signal bagi pihak eksternal untuk mengambil keputusan, sebagaimana dijelaskan oleh signaling theory. Signaling theory menurut Karasek dan Bryant merupakan hubungan antara pengungkapan informasi perusahaan dengan keputusan investasi pihak di luar perusahaan. Dari pandangan psikologi industri signaling theory tidak hanya sinyal untuk konsumen, investor atau pihak luar perusahaan tetapi juga mungkin sinyal kepada karyawan atau pihak perusahaan saat ini dan masa yang akan datang. ${ }^{8}$ Oleh karena itu pemberian atau pengungkapan Islamic Corporate Identity dalam laporan tahunan bank syariah memiliki dampak positif terhadap reputasi bank syariah dan pada akhirnya dapat meningkatkan profit.

Berbagai hasil studi berkaitan dengan Islamic Corporate Identity telah banyak dilakukan sebelumnya. Diantaranya dilakukan oleh Sukardi, hasil penelitiannya menyimpulkan bahwa bank dengan indeks Islamic Corporate Identity terbaik adalah BSM (94\%), BMI 90,7\%, BRI Syariah (89,2\%), BNI Syariah (88,3\%), BCA Syariah (87,8\%), Bank Jabar Banten Syariah (86,8\%), Bank Syariah Bukopin (86\%), Bank Syariah Mega Indonesia $(80,4 \%)$, Bank Maybank Syariah Indonesia (80,1\%), Bank Panin Syariah $(79,1 \%)$, dan Bank Victoria Syariah (73,8\%). ${ }^{9}$ Penelitian selajutnya adalah penelitian yang dilakukan oleh

\footnotetext{
${ }^{4}$ Eka Laily Romadhani and Rofiul Wahyudi, "Pengaruh Islamic Corporate Identity (ICI) Terhadap Kinerja Bank Syariah Di Indonesia," Jurnal Muqtasid 6, no. 2 (2015): 125-140.

${ }^{5} \mathrm{P}$ Berrone, J Surroca, and JA Tribo, "Corporate Ethical Identity as a Determinant of Firm Performance: A Test of the Mediating Role of Stakeholder Satisfaction," Journal of Business Ethics 76, no. 1 (2007): 119.

${ }^{6}$ Peter W Roberts and Grahame R Dowling, "Corporate Reputation And Sustained Superior Financial Performance," Strategic Management Journal 23, no. 2 (2002): 1077-93..

7 Roszaini Haniffa and Mohammad Hudaib, "Exploring the Ethical Identity of Islamic Banks via Communication in Annual Reports," Journal of Business Ethics 76, no. 1 (2007): 97-116.

${ }^{8}$ Ray Karasek and Phil Bryant, "Signaling Theory: Past, Present, and Future," Academy of Strategic Management Journal 11, no. 1 (2012): 1-10.

${ }_{9}^{9}$ Sukardi and Wijaya, "Corporate Ethical Identity, hlm 356
} 
Paramitasari. Hasil dari penelitian ini adalah pada tahun 2007, 2008, dan 2009 telah mendekati standar pelaporan ideal yang mencerminkan Islamic Corporate Identity. ${ }^{10}$

Kedua penelitian di atas hanya menghasilkan indeks-indeks Islamic Corporate Identity. Penelitian lain yang lebih spesifik mengenai Islamic Corporate Identity dilakukan oleh Ariyanto, dimana Islamic Corporate Identity menjadi variabel yang dapat mempengaruhi kinerja keuangan. Hasilnya adalah Islamic Corporate Identity memiliki pengaruh yang signifikan terhadap profit bank syariah yang diukur dengan ROA (Return on Asset) dan ROE (Return on Equity). ${ }^{11}$ Penelitian serupa juga dilakukan oleh Romadhani dan Wahyudi, dimana hasil penelitiannya menyimpulkan bahwa Islamic Corporate Identity berpengaruh terhadap CAR, FDR dan NPF. Sementara itu Islamic Corporate Identity tidak berpengaruh terhadap ROA, ROE dan BOPO.12

Dari hasil-hasil penelitian yang telah dilakukan sebelumnya maka masih ada kesenjangan hasil penelitian dimana Islamic Corporate Identity menurut hasil penelitian tidak memiliki pengaruh terhadap profitabilitas bank syariah, di lain sisi ada penelitian yang membuktikan sebaliknya. Dimana Islamic Corporate Identity memiliki pengaruh yang signifikan terhadap profitabilitas perbankan syariah. Dengan demikian penelitian meningkatkan profitabilitas dengan menerapkan Islamic Corporate Identity penting untuk dilakukan.

\section{METODE PENELITIAN}

Studi ini adalah termasuk dalam studi dengan desain pendekatan kuantitatif. Studi kuantitatif merupakan studi yang menuntut untuk menggunakan angka dalam melakukan analisis data. ${ }^{13}$ Adapun objek dari studi ini adalah laporan tahunan dari bank umum syariah di Indonesia pada tahun 2014-2017 yang terdiri atas bank Muamalat, BRI Syariah, Bank Syariah Mandiri, Bank BNI Syariah, Bank Jabar Banten Syariah, Bank Mega Syariah, BTPN Syariah, bank Panin Syariah, Mybank Syariah, Bukopin Syariah, Victoria Syariah dan BCA Syariah.

Jenis data yang digunakan dalam studi ini adalah data sekunder. Data sekunder adalah data yang dalam memperolehnya tidak dilakukan secara langsung oleh peneliti sendiri, ${ }^{14}$ tetapi menggunakan data-data yang telah dikumpulkan oleh peneliti atau pihak lain. Data sekunder dalam studi ini diperoleh melalui laporan tahunan yang dipublikasikan oleh masing-masing bank umum syariah di Indonesia.

Variabel pada studi ini terdiri atas dua variabel yaitu variabel independen dan variabel dependen. Variabel independen dalam studi ini adalah Islamic Corporate Indentity dan variabel dependen dalam studi ini adalah profitabilitas. Islamic Corporate Indentity pada studi ini diukur dengan menggunakan Islamic Corporate Indentity yang dikembangkan oleh ${ }^{15}$. Variabel Islamic Reporting Disclosure terdiri atas beberapa unsur yaitu 1) Pernyataan Visi dan Misi, 2) Dewan Komisaris dan Manajemen Puncak, 3) Produk dan Layanan, 4) Zakat, Infak, dan Shodaqoh, serta Dana Kebajikan, 5) Komitmen terhadap Karyawan, 6) Komitmen terhadap Debitur, 7) Komitmen terhadap Lingkungan Masyarakat dan 8) Dewan Pengawas Syariah. Dengan demikian variabel Islamic Corporate Indentity terdiri dari delapan unsur.

\footnotetext{
10 Paramitasari, "Islamic Corporate Identity in, hlm 44

11 Ariyanto, "Analisis Pengaruh Pengungkapan Identitas, hlm 110

12 Romadhani and Wahyudi, "Pengaruh Islamic Corporate, hlm 140

13 Suharsimi Arikunto, Prosedur Penelitian: Suatu Pendekatan Praktik (Jakarta: Rineke Cipta, 2013), 27

${ }^{14}$ Purwanto, Teknik Penyusunan Instrumen Uji Validitas Dan Reliabilitas Penelitian Ekonomi Syariah (Magelang: StaiaPress, 2018), 15

15 Haniffa dan Hudaib, Exploring the Ethical Identity, 97
} 
Adapun profitabilitas didasarkan pada indikator Return on Asset (ROA).ROA dihitung dengan cara membagi laba sebelum pajak dengan rata-rata total aset dalam suatu periode.

Guna menjawab tujuan dari studi ini maka teknik analisis data yang digunakan adalah analisis regresi data panel. Regresi data panel merupakan analisis regresi dimana data yang digunakan adalah data gabungan dari cross-section dan time-series. ${ }^{16}$ Dalam melakukan analisis regresi data panel ada tiga model yang ditawarkan yaitu Common Effect, Fixed Effect dan Random Effect. Model Common Effect merupakan teknik yang paling sederhana mengasumsikan bahwa data gabungan (data time series dan cross section) yang ada menunjukkan kondisi yang sesungguhnya. Sementara itu model yang kedua adalah model regresi fixed effect. Efek tetap di sini maksudnya adalah bahwa satu objek, memiliki konstan yang tetap besarnya untuk berbagai periode waktu. Ketiga random effect, random effect tidak menggunakan variabel semu tetapi menggunakan residual yang diduga memiliki hubungan antar waktu dan antar objek. ${ }^{17}$

Dari uraian mengenai regresi data panel di atas maka ada tiga model yang harus dipilih dalam analisis data dengan regresi data panel, sehingga diperlukan uji kesesuaian model.Uji kesesuaian model ini dimaksudkan agar model dalam regresi adalah model yang terbaik. Serangkaian pengujian untuk memilih model yang tepat terdiri dari chow test (uji Fstatistik), uji langrange multiplier (LM test), dan uji Hausman ${ }^{18}$. Uji Chow dilakukan guna menentukan apakah pada suatu model regresi data panel model yang terbaik menggunakan Common Effect atau fixed effect. Uji yang selanjutnya adalah uji Langrange Multiplier atau biasa dikenal dengan uji LM test. Uji ini dilakukan untuk mengetahui apakah model yang terbaik adalah model Common Effect ataukah Random effect. Uji yang selanjutnya adalah uji Hausman. Uji ini dilakukan guna menentukan apakah model yang terbaik dalam model regresi data panel adalah menggunakan fixed effect atau random effect. ${ }^{19}$

\section{HASIL DAN PEMBAHASAN}

Analisis data dalam studi ini hanya melibatkan 12 bank Umum Syariah, sehingga total data dalam studi ini sebanyak 48 data. Jumlah ini diperoleh dari 12 Bank Umum Syariah dikali 4 (data tahun 2014-2017). Dari hasil analisis data maka diperoleh hasil-hasil sebagai berikut:

\section{Uji Kesesuaian Model}

Dalam analisis data dengan menggunakan data panel maka diperlukan uji kesesuaian model. Uji ini dilakukan guna menentukan model yang paling tepat dalam melakukan analisis data.Uji yang pertama adalah uji $\mathrm{F}$ atau uji chow dilakukan untuk memilih antara model common effect ataukah fixed effect. Kemudian uji hausman, yaitu uji yang dilakukan untuk memilih random effect ataukah fixed effect. Dari hasil pengujian diperoleh hasil sebagai berikut:

\footnotetext{
16 Jaka Sriyana, Metode Regresi Data Panel (Dilengkapi Aplikasi Kinerja Bank Syariah Di Indonesia). (Yogyakarta: Ekonesia, 2014), 80

${ }^{17}$ Agus Widarjono, Ekonometrika Teori Dan Aplikasi Untuk Ekonomi Dan. Bisnis (Yogyakarta: Ekonesia, 2009), 238

18 Ibid

${ }^{19}$ Ibid
} 
Tabel 2.

Hasil Uji Kesesuain Model

\begin{tabular}{llll}
\hline Variabel Y Uji Model & Hasil & Kesimpulan \\
\hline \multirow{2}{*}{ ROA } & $\begin{array}{l}\text { Chow Test (Common effect } \text { or } 0.001 \\
\text { fixed effect) }\end{array}$ & Fixed Effect \\
\cline { 2 - 3 } & $\begin{array}{l}\text { Hasuman Test (fixed effect } \\
\text { Random effect }\end{array}$ & Fixed Effect \\
\hline
\end{tabular}

Sumber: Ouput eviews 9 (2019)

Dari hasil uji chow di atas maka dapat diketahui bahwa model terbaik adalah dengan mengetahui apakah model menggunakan common effect atau model menggunakan fixed effect. Dari hasil uji-F (Cross-section) nilai probalitasnya $>0,05$ sehingga dapat disimpulkan bahwa model yang terbaik adalah dengan menggunakan fixed effect. Tahap selanjutnya adalah melakukan uji hausman. Uji ini dilakukan guna menentukan model terbaik diantara model random effect ataukah fixed effect. Dari hasil pengujian diperoleh nilai probabilitas cross-section $\mathrm{F}$ bernilai $0,010<0,05$. Dari hasil pengujian kesesuaian model maka dapat disimpulkan bahwa model Fixed effect merupakan model yang terbaik dalam studi ini.

\section{Analisis Model Data Panel}

Berdasarkan hasil uji pengujian pemilihan model, dapat disimpulkan bahwa model yang terbaik dalam studi ini adalah Fixed effect.

Tabel 3

Hasil Estimasi Fixed Effect

\begin{tabular}{lllll}
\hline Variable & Coefficient & Std. Error & t-Statistic & Prob. \\
\hline C & -1.196321 & 0.400481 & -2.987211 & 0.0051 \\
ID? & 1.498530 & 0.493054 & 3.039281 & 0.0045 \\
Fixed Effects (Cross) & & & & \\
_MUAMALAT-C & -0.075356 & & & \\
_BRI-C & 0.031006 & & & \\
_BSM-C & 0.181812 & & \\
_BNI-C & -0.068212 & & \\
_BJB-C & -0.158012 & & \\
_MEGA-C & -0.069887 & & \\
_BTPN-C & 0.124461 & & \\
_PANIN-C & -0.055938 & & \\
_MYBANK-C & 0.021098 & & \\
-BUKOPIN-C & -0.048881 & & \\
_VICTORIA-C & 0.079310 & & \\
_BCA-C & 0.038599 & & \\
& Effects Specification & & \\
R-squared & 0.482346 & Mean dependent var & 0.020317 \\
Adjusted R-squared & 0.304865 & S.D. dependent var & 0.098775 \\
S.E. of regression & 0.082353 & Akaike info criterion & -1.929785 \\
Sum squared resid & 0.237372 & Schwarz criterion & -1.423001 \\
Log likelihood & 59.31483 & Hannan-Quinn criter. & -1.738270 \\
F-statistic & 2.717729 & Durbin-Watson stat & 1.946571 \\
Prob(F-statistic) & 0.010520 & & \\
\hline
\end{tabular}

Sumber: Ouput eviews 9 (2019) 
Meningkatkan Profitabilitas Dengan Menerapkan Islamic Corporate Identity (Studi Pada Bank Umum Syariah di Indonesia Tahun 2014-2017)

Dari tabel 3 dapat diketahui bahwa variabel Islamic Corporate Indentity berpengaruh signifikan negatif terhadap Profitabilitas (ROA). Hal ini dapat dilihat pada probabilitas variabel Islamic Corporate Indentity yang bernilai $0.0045<0,05$.

\section{Hasil Uji Hipotesis dan Analisis}

Dari hasil analisis regresi data panel diperoleh hasil bahwa variabel Islamic Corporate Indentity pada Bank Umum Syariah di Indonesia tahun 2014-2017 berpengaruh signifikan positif terhadap Profitabilitas (ROA) hal ini dapat dilihat dari nilai Prob 0,0045 > 0,05. Dengan demikian semakin baik Islamic Corporate Indentity pada Bank Umum Syariah maka profitabilitas bank syariah akan semakin besar.

Sebagai lembaga bisnis yang berbasis Islam pada dasarnya perbankan syariah harus memegang nilai-nilai bisnis dalam Islam. Nilai-nilai tersebut menurut Hulaimi dkk adalah 1) jujur dan transparan. 2) Menjual barang yang baik mutunya. 3) Tidak menggunakan sumpah. 4) Longgar dan bermurah hati. 5) Membangun hubungan baik dengan kolega. ${ }^{20}$ Nilai-nilai bisnis dalam Islam ini kemudian diturunkan menjadi Islamic Corporate Identity. Jadi Islamic Corporate Identity yang tinggi menunjukkan bahwa suatu entitas bisnis telah menerapkan nilai-nilai Islam dalam pelaksanaan bisnisnya.

Haniffa dan Hudaib ada dimensi dari Islamic Corporate Identity yaitu 1) Pernyataan Visi dan Misi, 2) Dewan Komisaris dan Manajemen Puncak, 3) Produk dan Layanan, 4) Zakat, Infak, dan Shodaqoh, serta Dana Kebajikan, 5) Komitmen terhadap Karyawan, 6) Komitmen terhadap Debitur, 7) Komitmen terhadap Lingkungan Masyarakat dan 8) Dewan Pengawas Syariah.

Dimensi pertama, kedua dan ketiga (pernyataan visi misi dan informasi lengkap tentang dewan komisaris dan manajemen puncak serta Produk dan Layanan) merupakan filosofi dan nilai yang mendasari bank syariah dalam menjalankan operasional. Dengan prinsip ini maka perbankan syariah dapat melaksanakan prinsip bisnis Islam seperti jujur dan transparan dan hanya menjual produk yang baik mutunya karena produk tidak mengandung riba yang sangat dilarang oleh ajaran agama Islam.

Dimensi-dimensi selanjutnya dari Islamic Corporate Identity seperti zakat, sedekah dan pinjaman kebajikan; dimensi komitmen terhadap karyawan; dimensi komitmen terhadap debitur; dimensi komitmen kepada masyarakat diturunkan dari prinsip fokus pada tujuan pengembangan dan sosial. Merupakan implementasi dari longgar dan bermurah hati serta membangun hubungan baik dengan kolega (nasabah dan investor) dalam menjalankan bisnisnya. Dengan adanya dimensi ini maka bank syariah pada dasarnya telah melaksanakan nilai-nilai bisnis Islam.

Sedangkan dimensi terakhir yang membahas Dewan Pengawas Syariah adalah penjabaran dari prinsip tinjauan oleh Dewan Pengawas Syariah. ${ }^{21}$ Dimensi ini pada dasarnya untuk menjamin bahwa akad-akad dalam transaksinya terjamin kehalalannya. Dengan demikian penerapan Islamic Corporate Identity pada dasarnya adalah sebagai bentuk komitmen dari bank syariah untuk menerapkan nilai-nilai Islam dalam aktivitas bisnisnya. Perbankan syariah yang menerapkan Islamic Corporate Identity dalam kegiatan bisnisnya dengan sendirinya dapat meningkatkan kepercayaan kepada nasabahnya, dan pada akhirnya dapat meningkatkan profitabilitasnya.

20 Ahmad Hulaimi, Sahri, dan Moh Huzaini, "Etika Bisnis Islam Pedagang Sapi Dan Dampaknya Terhadap Kesejahteraan Pedagang Di Kecamatan Masbagik Kabupate Lombok Timur," Iqtishadia: Jurnal Ekonomi Dan Perbankan Syariah 3, no. 2 (2016), hlm 352.

${ }^{21}$ Ibid

Iqtishadia: Jurnal Ekonomi dan Perbankan Syariah 
Profitabilitas merupakan salah satu cara untuk menilai bagaimana sebuah perusahaan mampu menghasilkan laba dalam periode tertentu. ${ }^{22}$ Setiap perusahaan didirikan pada dasarnya untuk mendapatkan laba sehingga setiap perusahaan akan berusaha untuk meningkatkan labanya. Bagi nasabah, sebelum menempatkan dananya di bank syariah mereka akan melihat terlebih dahulu kinerja keuangan bank tersebut melalui laporan keuangan berupa neraca dan laba rugi. Hal ini dikarenakan semakin besar keuntungan yang diperoleh bank syariah maka akan semakin besar pula imbal bagi hasilnya. Tinggi rendahnya profit pada bank syariah dapat dilihat dari rasio profitabilitas yang di ukur dengan Return on Assets (ROA).23

Semakin besar rasio ROA maka akan semakin baik posisi bank tersebut dari segi penggunaan kekayaan yang dimiliki oleh perbankan syariah. Sesuai dengan Surat Edaran Bank Indonesia Nomor 12/11/DPNP tanggal 31 Maret 2010 tentang Sistem Penilaian Tingkat Kesehatan Bank Umum ROA dapat dihitung dengan cara membagi laba sebelum pajak dengan rata-rata total aset. Tinggi rendahnya profitabilitas bank dapat ditentukan oleh faktor internal dan faktor eksternal. Faktor internal dapat berupa produk bank, besar kecilnya imbal bagi hasil yang ditawarkan reputasi dan kualitas layanan. Adapun faktor eksternal meliputi kondisi perekonomian, peraturan Bank Indonesia, perkembangan pasar uang dan pasar modal. ${ }^{24}$

Dari hasil pengujian hipotesis membuktikan bahwa penerapan Islamic Corporate Indentity memiliki pengaruh yang signifikan positif terhadap profitabilitas perbankan syariah. Dengan demikian semakin tinggi Islamic Corporate Indentity maka akan semakin baik pula profitabilitas perbankan syariah. Hasil penelitian ini mendukung penelitian yang dilakukan oleh Ariyanto, ${ }^{25}$ dimana Islamic Corporate Indentity memiliki pengaruh yang positif terhadap profitabilitas bank syariah. Dengan demikian hasil penelitian ini menentang hasil penelitian yang dilakukan oleh Romadhani dan Wahyudi, ${ }^{26}$ yang menyatakan bahwa Islamic Corporate Indentity tidak memiliki pengaruh yang signifikan terhadap profitabilitas bank syariah.

Dari segi teori hasil penelitian ini mendukung signaling theory. Secara sederhana signaling theory dapat dipahami bahwa investor atau pihak eksternal membutuhkan informasi yang akurat untuk menentukan apakah ia akan melakukan investasi ataukah tidak. Signaling theory menurut Karasek dan Bryant pada dasarnya adalah menjelaskan keterkaitan antara pengungkapan informasi mengenai perusahaan dengan keputusan pihak eksternal untuk melakukan investasi. Dari pandangan psikologi industri, signaling theory tidak hanya sinyal untuk konsumen, investor atau pihak luar perusahaan tetapi juga mungkin sinyal kepada karyawan atau pihak perusahaan saat ini dan masa depan. ${ }^{27}$ Informasi mengenai perusahan diperlukan oleh para calon investor untuk melakukan investasi ataukah tidak. Investor tidak hanya mempertimbangkan informasi keuangan, namun juga membutuhkan informasi mengenai etika dalam penilaian mereka terhadap perusahaan. Pernyataan etis dapat sebagai sinyal positif tentang sumber daya perusahaan28. Dengan demikian pengungkapan Islamic Corporate Identity dalam laporan keuangan perbankan syariah dapat

\footnotetext{
${ }^{22}$ M M Hanafi and A Halim, Analisis Laporan Keuangan (Yogyakarta: STIM YKPN, 2007), 84

${ }^{23}$ Nur Mawaddah, "Faktor-Faktor yang Mempengaruhi Profitabilitas," Etikonomi 14, no. 2 (2015): 24156.

24 Ibid, 246

25 Ariyanto, "Analisis Pengaruh ..."

26 Romadhani and Wahyudi, "Pengaruh Islamic Corporate Identity (ICI)..."

${ }^{27}$ Karasek and Bryant, "Signaling Theory: Past, Present, and Future, hlm 5

28 S A Waddock and SB Graves, "The Corporate Social Performance-Financial Performance Link. Strategic Management Journal," Strategic Management Journal 18, no. 4 (1997): 303-19.
} 
Meningkatkan Profitabilitas Dengan Menerapkan Islamic Corporate Identity (Studi Pada Bank Umum Syariah di Indonesia Tahun 2014-2017)

memberikan informasi bagi para calon investor bahwa perbankan syariah menerapkan Islamic Corporate Identity yang baik, sehingga semakin baik penerapan Islamic Corporate Identity maka semakin banyak kesempatan bagi perbankan syariah untuk mendapatkan investor dan pada akhirnya dapat meningkatkan profitabilitasnya.

\section{PENUTUP}

Dari hasil analisis regresi data panel diperoleh hasil bahwa variabel Islamic Corporate Indentity pada Bank Umum Syariah di Indonesia tahun 2014-2017 berpengaruh signifikan positif terhadap Profitabilitas (ROA) hal ini dapat dilihat dari nilai Prob 0,0045 > 0,05. Dengan demikian semakin baik Islamic Corporate Indentity pada Bank Umum Syariah maka profitabilitas bank syariah akan semakin besar. Penelitian ini hanya melibatkan bank umum syariah di Indonesia, sehingga untuk penelitian selanjutnya diharapkan dapat melibatkan Bank Pembiayaan Rakyat Syriah dan Unit Usaha Syariah. Selain itu penelitian selanjutnya dapat menambah variabel independen seperti variabel makro ekonomi dan daya beli masyarakat.

\section{DAFTAR PUSTAKA}

Arikunto, Suharsimi. Prosedur Penelitian: Suatu Pendekatan Praktik. Jakarta: Rineke Cipta, 2013.

Ariyanto, Taufik. "Analisis Pengaruh Pengungkapan Identitas Etis Islam Terhadap Kinerja Keuangan Bank Syariah Di Asia." Jurnal Akuntasi Dan Keuangan 1, no. 1 (2014): 98110.

Berrone, P, J Surroca, and JA Tribo. "Corporate Ethical Identity as a Determinant of Firm Performance: A Test of the Mediating Role of Stakeholder Satisfaction." Journal of Business Ethics 76, no. 1 (2007): 1-19.

Haniffa, Roszaini, and Mohammad Hudaib. "Exploring the Ethical Identity of Islamic Banks via Communication in Annual Reports." Journal of Business Ethics 76, no. 1 (2007): 97116. https://doi.org/10.1007/s10551-006-9272-5.

Hulaimi, Ahmad, Sahri, and Moh Huzaini. "Etika Bisnis Islam Pedagang Sapi Dan Dampaknya Terhadap Kesejahteraan Pedagang Di Kecamatan Masbagik Kabupate Lombok Timur." Iqtishadia: Jurnal Ekonomi Dan Perbankan Syariah 3, no. 2 (2016): 344-64.

Karasek, Ray, and Phil Bryant. "Signaling Theory: Past, Present, and Future." Academy of Strategic Management Journal 11, no. 1 (2012): 1-10.

Paramitasari, Ratih. "Islamic Corporate Identity in the Practice of Annual Report Disclosure Islamic Bank." ASSETS: Jurnal Akuntansi Dan Pendidikan 1, no. 1 (2012): 34-44.

Purwanto. Teknik Penyusunan Instrumen Uji Validitas Dan Reliabilitas Penelitian Ekonomi Syariah. Magelang: StaiaPress, 2018.

Roberts, Peter W, and Grahame R Dowling. "Corporate Reputation And Sustained Superior Financial Performance.” Strategic Management Journal 23, no. 2 (2002): 1077-93. https://doi.org/10.1002/smj.274.

Romadhani, Eka Laily, and Rofiul Wahyudi. "Pengaruh Islamic Corporate Identity (ICI) Terhadap Kinerja Bank Syariah Di Indonesia." Jurnal Muqtasid 6, no. 2 (2015): 12540.

Sriyana, Jaka. Metode Regresi Data Panel (Dilengkapi Aplikasi Kinerja Bank Syariah Di Indonesia). Yogyakarta: Ekonesia, 2014.

Sukardi, Budi, and Taufiq Wijaya. "Corporate Ethical Identity Perbankan Syariah Di Indonesia." Jurnal Tsaqafah 9, no. 2 (2013): 337-56. 
Waddock, S A, and SB Graves. "The Corporate Social Performance-Financial Performance Link. Strategic Management Journal." Strategic Management Journal 18, no. 4 (1997): 303-19.

Widarjono, Agus. Ekonometrika Teori Dan Aplikasi Untuk Ekonomi Dan. Bisnis. Yogyakarta: Ekonesia, 2009. 